УДК 371.132

DOI: $10.35619 /$ iiu.v1i10.187

\author{
Кононко Олена \\ доктор психологічних наук, професор, \\ завідувачка кафедри дошкільної освіти Ніжинського \\ державного університету імені Миколи Гоголя, \\ м. Ніжин, Україна \\ ORCID: 0000-0003-2815-6261 \\ e-mail: kononko11@ukr.net
}

\title{
ОСОБИСТІСНА КОМПЕТЕНТНІСТЬ МАЙБУТНЬОГО ПЕДАГОГА: ЗМІСТ, СТРУКТУРА, УМОВИ ФОРМУВАННЯ
}

Анотація. У матеріалах висвітлено концептуальний та технологічний підходи до проблеми формування особистісної компетентності майбутніх педагогів дошкільної освіти. Їх актуальність обумовлюється браком теоретичних та експериментальних досліджень означеного напряму, трансформацією морально-духовних цінностей сучасної молоді, затребуваністю закладами вищої освіти інформації щодо шляхів ефективного формування в майбутніх педагогічних кадрів особистісної компетентності як складного i вкрай важливого феномену. Під «особистісною компетентністю» розуміється інтегральна характеристика майбутнього фахівця, яка засвідчується його здатністю свідомо мотивувати, організовувати, регулювати, контролювати та адекватно оцінювати результативність своєї життєдіяльності й вкладених в неї особистісних зусиль, творчо й соціально прийнятно самовиражатися, уміло розв'язувати проблеми, реалізовувати свої потенційні можливості, орієнтуватися на духовні цінності, набувати індивідуального досвіду, домагатися життєвого успіху. Критеріями оцінки типу сформованості особистісної компетентності слугували: міра реалізації майбутнім педагогом дошкільної освіти свого інтелектуального, емоційноціннісного, соціально-морального, вольового та рефлексивного потенціалів; прояви творчої активності, висока продуктивність навчальної та педагогічної діяльності, задоволеність життям. Схарактеризовано чотири типи особистісної компетентності: продуктивно-креативний, продуктивно-реконструктивний, продуктивновідтворювальний та деструктивний. Умовами ефективного формування особистісної компетентності у закладі вищої освіти є: розвиток рефлексивних рис особистості, адекватного Я-образу; формування цілісної реалістичної картини світу, наукового світогляду та смислу життя; вправляння в умінні довіряти особистісному досвіду; виховання системи духовних цінностей; забезпечення балансу соціальних та індивідуальних потреб, професійних та особистих інтересів; прищеплення корисних звичок.

Ключові слова: потенційне та актуальне, потенціали особистості, життєвий досвід, життєздатність особистості, креативність, особистісна компетентність, баланс індивідуальних та соціальних інтересів.

Постановка проблеми. Проблема особистості віддзеркалює нагальні потреби сучасності. Суспільство потребує людей самостійних, креативних, здатних самовизначатися у плинному світі, організовувати та контролювати власну життєдіяльність, відповідати за наслідки своїх дій і вчинків. Важливим завданням закладів вищої освіти $є$ не лише якісна професійна підготовка педагогічних кадрів, а й формування особистісної компетентності студентської молоді, виховання в неї моральної за змістом та активної за формою життєвої позиції, розвиток цілісної наукової картини світу та адекватного Я-образу. 
Як засвідчує аналіз наукових джерел, особистісна компетентність досліджується вітчизняними та зарубіжними фахівцями переважно в контексті професійної компетентності, розглядається як іiі складова і здебільшого кваліфікується як певна сукупність професійно важливих якостей. Це звужує складну наукову проблему i актуалізує необхідність дослідження особистісної компетентності як ключової категорії, результату та умови ефективної педагогічної діяльності.

Аналіз останніх досліджень 3 проблеми. Упровадження в педагогічну практику особистісно орієнтованого підходу посилило інтерес до проблеми особистісного зростання студентської молоді, суті нової парадигми освіти та умов іiі ефективної реалізації. Як зауважує В. Сєриков, освіта неможлива поза зверненням до особистості. Справа лише у тому, яку роль відіграє вона у цьому процесі - мети чи засобу. Автор підкреслює: традиційна освіта переслідувала цілі функціональної, предметно-речової освіченості молодої людини, використовувала особистість у ролі засобу. Особистісно орієнтована освіта розглядає механізми особистісного існування - рефлексію, смислотворення, вибірковість, автономність, відповідальність тощо як самоціль. На думку В. Сєрикова, ефективність засвоєння студентами власне предметного змісту зростає завдяки тому, що він набуває якісно нового особистісного смислу, постає змістом та середовищем становлення особистісного досвіду. За умов особистісної методології освіта $є$ гуманітарною системою 3 особливими закономірностями функціонування і розвитку (1998).

Характеризуючи стратегію модернізації національної освіти України, В. Кремень зазначає, що цей процес відбувається в умовах істотних змін в духовному просторі суспільства. Він підкреслює: філософія освіти має зосереджувати увагу на ії зв'язку 3 філософсько-світоглядною проблематикою. Указуючи на значну роль у формуванні гуманістичної філософії освіти особистісно орієнтованої моделі, В. Кремень підкреслює: розвиток молоді є однією з найвищих освітніх цінностей. Насиченість освітнього простору гуманістичним змістом, культурними орієнтаціями $є$ однією із засад сучасної філософії освіти. Культурологічна модель освіти має спрямовуватися на особистість, на її включення у процес культурної творчості (2002).

Орієнтація сучасного процесу підготовки педагогічних кадрів на компетентнісний підхід актуалізує проблему «особистісної компетентності». Як засвідчує аналіз наукових джерел, особистісна компетентність багатьма науковцями розглядається як складова професійної і зводиться здебільшого до сукупності професійно важливих якостей. Так Т. Синенко, досліджуючи особистісну компетентність студентів педагогічних закладів, виділила чотири блоки професійно значущих особистісних якостей, які, на ії думку, складають особистісну компетентність майбутніх фахівців. До них віднесено: загальнолюдські цінності; якості, що характеризують психологічну грамотність студента; якості, що сприяють самоактуалізації особистості; якості, які забезпечують стійку професійну позицію педагога (2009).

У контексті моделювання педагогічної компетентності В. Введенський розглядає компетентність як особистісну характеристику і трактує ії як: єдність знань і умінь; обсяг навичок; комбінацію професійно значущих особистісних якостей і властивостей; вектор професіоналізації; єдність теоретичної і практичної готовності до майбутньої діяльності; здатність здійснювати складні культуродоцільні види дій. На нашу думку, вказане трактування надміру широке, ускладнює розуміння співвідношення понять «особистісний» та «професійний», ігнорує такі важливі складові особистісного зростання, як самостійність, креативність, самовизначення, світоглядна позиція тощо (2003).

А. Маркова кваліфікує компетентність як індивідуальну характеристику, ступінь відповідності молодої людини вимогам професії. Вона виділяє спеціальний, соціальний, особистісний та індивідуальний види професійної компетентності. Правомірність такого розподілу викликає сумніви $з$ огляду на те, що особистість єдність індивідуального і соціального. Автор включає особистісну компетентність до 
складу професійної і визначає ії як єдність таких характеристик: володіння досвідом саморегуляції, прийомами самовираження і саморозвитку, засобами протистояння професійним деформаціям (1996).

Поняттям «професійно-особистісна компетентність» оперує О. Сахарчук, акцентуючи увагу на мотивованому прагненні майбутнього фахівця до професійноособистісної освіти, системного бачення педагогічної реальності, креативності та професійно-особистісної рефлексії. Констатуючи важливість вказаних автором характеристик, вважаємо недоцільним об'єднане використання категорії, яка потребує визначення специфіки кожної складової інтегралу.

У полі уваги М. Сергєєва знаходиться модель випускника закладу вищої освіти педагогічного профілю. Цікавою видається спроба автора виділити єдність особистісних блоків, значущих для нього: світоглядні установки і моральні якості мотивуюче ядро; здібності до вироблення індивідуального педагогічного стилю; система умінь і навичок, необхідних для розвитку особистості майбутніх вихованців; знання як наукова картина світу. Заслуговує позитивної оцінки спроба автора збалансувати у своїй моделі світоглядні та поведінкові аспекти розвитку особистості, проте залишається незрозумілим, по-перше, чому світоглядні установки та наукова картина світу віднесені до різних особистісних блоків і, по-друге, чому недостатньо уваги приділено самостійності, креативності, ціннісним орієнтаціям (2013).

Вітчизняні фахівці характеризують особистісні якості переважно в контексті проблеми професійної компетентності майбутнього педагога. При цьому перевага надається таким якостям, як: творче використання знань на практиці, критичність, організаторські здібності (В. Бондар); любов до дітей, вимогливість, емпатія, комунікативність (Г. Бєлєнька); здатність до самовизначення, творчого самовираження, саморозвитку та самоосвіти (І. Зязюн); світоглядна позиція, емоційна сприйнятливість, самостійність, креативність, наполегливість (С. Нечай). Усі зазначені якості та властивості важливі для оцінки особистісної компетентності, проте вони подані вибірково, в контексті іншої проблеми, схарактеризовані відокремлено від особистісної компетентності як такої.

Спробу розробити цілісну модель особистісної компетентності здійснив американський фахівець McClelland. Він виділив декілька іiі рівнів, схарактеризував кожний. До першого відніс інструментальні знання і навички; до другого - соціальні та комунікативні уміння, здатність орієнтуватися в середовищі; до третього - норми, цінності, стандарти поведінки, моральні критерії, володіння правилами етикету; до четвертого, базового, рівня моделі - ентузіазм, мотиви і самооцінку. На відміну від попередніх, вказана модель, по-перше, містить суто особистісні характеристики, подруге, відрізняється спробою подати цілісну характеристику інтегрального явища, потретє, визначає динаміку розвитку особистості.

Екскурс у наукову літературу дозволяє говорити про актуальність дослідження, присвяченого особистісній компетентності майбутнього педагога як складному психолого-педагогічному феномену.

Мета статті: розкрити феноменологію особистісної компетентності як інтегрального явища; визначити критерії, показники та схарактеризувати типи іiі розвитку в майбутніх педагогів; розкрити психолого-педагогічні умови формування особистісної компетентності студентської молоді в закладах вищої освіти.

Виклад основного матеріалу дослідження. Теоретичним підгрунтям дослідження слугувала концепція розробки проблеми компетентності Дж. Равена. Згідно $з$ його підходом, розвиток компетентності відбувається ефективно за умови, що базовими характеристиками є система особистих цінностей, життєвих пріоритетів молодої людини, внутрішні мотиви. На думку автора, у полі зору експерта компетентності мають знаходитися продуктивність життєдіяльності, задоволеність студента життям особистим і професійним, тип його поведінки. До основних якостей, що потребують 
оцінки, фахівцем віднесено ініціативність, самовідданість, оптимізм, відповідальність (2002).

У цих матеріалах подано авторське визначення змісту та структури провідної категорії. Особистісну компетентність тлумачимо як інтегральну характеристику майбутнього фахівця, яка засвідчується його здатністю свідомо мотивувати, організовувати, регулювати, контролювати та адекватно оцінювати результативність своєї життєдіяльності й вкладених у неї особистісних зусиль, творчо й соціально прийнятно самовиражатися, ефективно розв'язувати проблеми, реалізовувати свої потенційні можливості, орієнтуватися на духовні цінності, набувати індивідуального досвіду, домагатися життєвого успіху.

У контексті особистісної компетентності важливими для нас поняттями були «життєвий досвід» та «життєздатність» особистості. Нам імпонує підхід П. Корнєєва, який розуміє під життєвим досвідом концентроване вираження життя особистості, який набувається у процесі діяльності. До його складу автор відносить: практичні знання («знаю, як діяти»), уміння («можу виконати ці дії») та звички («завжди так учиняю»), забарвлені певними ставленнями. Фахівець наголошує на важливості набуття, освоєння та використання особистістю свого життєвого досвіду, переносу набутого в одних умовах досвіду в інші життєві ситуації (1985).

Оперуючи поняттям «життєвий досвід», розуміємо під ним систему знань, умінь, навичок, звичок, забарвлених ставленням особистості, що функціонує і розвивається в культурному контексті, стимулює зміни та оновлення звичних життєвих координат і установок, передбачає їх свідоме і доцільне перетворення. Процес набуття досвіду передбачає активну роботу душі майбутнього педагога дошкільної освіти, результатом якої виступає його духовна зрілість.

Узагальнення філософів, психологів і педагогів дозволяють говорити, що духовне існування $\epsilon$ результатом постійних особистісних зусиль, а життя - процесом постійного осмислення свого буття, усвідомлення його смислу. За своїм змістом смисл життя $є$ символіко-культурним утворенням, основні функції якого пов'язані 3 почуттям повноти життя. Під смислом життя розуміємо міру, якою особистість вимірює процес свого існування. Отже, вибір майбутнім педагогом свого життєвого шляху - це процес створення і перманентного коректування життєвого «сценарію».

У контексті особистісної компетентності актуалізується проблема співвідношення актуального і потенційного в розвитку особистості майбутнього педагога. Проблема потенціалу виступає об’єктом уваги А. Адлера, Б. Ананьєва, В. Ганзена, Л. Головей, С. Дружилова, Д. Леонтьєва, С. Рубінштейна, 3. Фрейда, Е. Фромма, К. Юнга та інших фахівців. Більшість із них використовують як синоніми поняття «потенціал» та «ресурс», констатуючи, що успішне виконання професійної діяльності, особливо у несприятливих умовах, актуалізує необхідність особистості використовувати свої внутрішні потенціали.

Загальнонаукове поняття «потенціал» уведене в обіг Арістотелем, який поділяв буття на «потенційне» та «актуальне», а особистісний розвиток розглядав як процес переходу від першого до другого. Б. Ананьєв зазначав, що суспільство ще вкрай рідко використовує наукові знання про резерви та ресурси особистості. В. Ганзен та Л. Головей оперують поняттям «потенціали індивідуального розвитку», до складу яких включають індивідні, суб'єктні та особистісні особливості. У дослідженнях Л. Почебута та В. Чикера використовується поняття «особистісний потенціал»; Д. Леонтьєва - «потенціал особистості», Т. Корнілова - «інтелектуально-особистісний потенціал» та «творчий потенціал»; С. Хазова - «ментальний ресурс» як змістова, відносно стабільна характеристика внутрішнього світу особистості.

Заслуговує на увагу думка С. Дружилова щодо існування певної сукупності властивостей особистості, яка характеризується як внутрішній потенціал, який забезпечує успішне освоєння професії, високоефективну професійну діяльність, розвиток особистості професіонала. Цю сукупність властивостей автор означив як 
«індивідуальний ресурс професійного розвитку» (ІРПР) i розробив концепцію становлення професіоналізму молодої людини як реалізацію іiї індивідуального потенціалу (2002).

Як зазначає О. Савченко, уведення в обіг поняття «особистісний потенціал» уможливило перехід від аналізу поведінки як детермінованої форми активності до розгляду різних форм самоорганізації особистості - самовизначення, саморегуляції, самореалізації тощо. На думку автора, рефлексивний потенціал - складова особистісного потенціалу, що забезпечує самоусвідомлення, саморегуляцію та самоорганізацію суб'єкта шляхом мобілізації рефлексивних ресурсів. Відповідно до підходу М. Бадалової, рефлексивний потенціал особистості може функціонувати на різних рівнях: на когнітивно-змістовому він забезпечує мисленнєву діяльність, на ціннісно-смисловому - узгоджує мислення 3 етичною та ціннісною сторонами професійної діяльності.

Відправним у нашому дослідженні слугувало сформульоване Д. Леонтьєвим положення, згідно 3 яким особистісний потенціал розглядається в контексті саморегуляції, життєстійкості, автономії, рефлексивності, які кваліфікуються автором як складові інтегралу. Відомий фахівець зазначає: коли йдеться про особистісний потенціал, маються на увазі не стільки базові риси та установки, скільки особливості системної організації особистості в иілому, ї̈ складна архітектоніка. На думку автора, особистісний потенціал - інтегральна характеристика рівня особистісної зрілості молодої людини (2011).

Оперуючи поняттям «рефлексія», ми, слідом за Б. Ананьєвим, Л. Виготським та С. Рубінштейном, розуміємо під ним пояснювальний принцип розвитку самосвідомості особистості, компонент структури ї̈ діяльності. Виходимо 3 положення, що завдяки рефлексії у внутрішньому плані відображається діяльність, що уможливлює спостереження, критику, самоаналіз, осмислення, переосмислення здобутків і прорахунків, удосконалення навчальної та професійної діяльностей.

Актуалізація студентською молоддю внутрішнього потенціалу - важлива умова формування ії особистісної компетентності. Міра, форма, широта, стабільність прояву назовні інтелектуального, емоційно-ціннісного, соціально - морального, вольового та рефлексивного потенціалів слугували критеріями оцінки типу особистісної компетентності майбутніх педагогів. У таблиці 1 схарактеризовано визначені у дослідженні критерії та показники розвитку в них особистісної компетентності.

Таблиия 1.

Критерії та показники оцінки особистісної компетентності майбутніх педагогів

\begin{tabular}{|c|c|}
\hline $\begin{array}{l}\text { КРИТЕРІЇ - } \\
\text { актуалізовані } \\
\text { потенціали: }\end{array}$ & ПОКАЗНИКИ \\
\hline Інтелектуальний & $\begin{array}{l}\text { Прагнення пізнавати нове, продукувати оригінальні ідеї, виявляти } \\
\text { новаторство, винахідництво, критичність, креативність; орієнтація } \\
\text { на доцільність і здоровий глузд; володіння життєво необхідними } \\
\text { та професійно значущими знаннями; уміння працювати } 3 \\
\text { інформацією, виявляти аналітичні здібності; використання } \\
\text { абстрактних категорій; усвідомлення важливості балансу потреб і } \\
\text { вимог життя. }\end{array}$ \\
\hline Емоційно-ціннісний & $\begin{array}{l}\text { Оптимізм, ентузіазм, сприйнятливість, емоційна стабільність; } \\
\text { ціннісні ставлення до світу та самої себе; розвиток соціальних та } \\
\text { індивідуальних мотивів; усвідомлення смислу життя; реалістична } \\
\text { картина світу та науковий світогляд; адекватна самооцінка, } \\
\text { ціннісне самоставлення, повага до оточуючих; надання переваг } \\
\text { комусь-чомусь; прагнення до успіху, задоволеність життям. }\end{array}$ \\
\hline $\begin{array}{l}\text { Соціально- } \\
\text { моральний }\end{array}$ & $\begin{array}{l}\text { Уміння працювати в команді, домовлятися, узгоджувати позиції, } \\
\text { поступатися, відстоювати істину, налагоджувати стосунки, } \\
\text { дружити, дотримуватися обіцянок; орієнтація на моральні та }\end{array}$ \\
\hline
\end{tabular}




\begin{tabular}{|c|c|}
\hline & $\begin{array}{l}\text { духовні цінності; спроможність самовиражатися соціально } \\
\text { прийнятим способом; виявляти власну гідність; відповідальність, } \\
\text { чуйність, справедливість, готовність допомогти та підтримати. }\end{array}$ \\
\hline Вольовий & $\begin{array}{l}\text { Здатність мобілізуватися на досягнення цілей, долати перешкоди, } \\
\text { доводити розпочате до кінця, поводитися впевнено, домагатися } \\
\text { високих стандартів якості; наполегливість, саморегуляція, } \\
\text { самовладання, автономність, ініціативність, здійснення } \\
\text { самостійних виборів, прийняття доцільних рішень, спроможність } \\
\text { аргументувати та відстояти позицію, підтримати себе та інших у } \\
\text { стресовій ситуації. }\end{array}$ \\
\hline Рефлексивний & $\begin{array}{l}\text { Уміння спостерігати за собою, визнавати свої чесноти і вади, } \\
\text { аналізувати й об’єктивно оцінювати досягнення та прорахунки, } \\
\text { співвідносити власні бажання і можливості, довіряти та } \\
\text { конструктивно ставитися до себе; брати до уваги очікування } \\
\text { авторитетних людей, вносити корективи у поведінку та } \\
\text { діяльність, реалізовувати свій природний потенціал і } \\
\text { орієнтуватися на подальший розвиток. }\end{array}$ \\
\hline
\end{tabular}

Орієнтуючись на визначені критерії та показники, враховуючи міру реалізації вказаних у таблиці потенціалів і стабільність прояву показників кожного з них, а також беручи до уваги, що провідними ознаками повноцінного особистісного буття є творча активність та висока продуктивність життя, виділено чотири типи особистісної компетентності майбутніх педагогів: продуктивно-креативний, продуктивнореконструктивний, продуктивно-відтворювальний, деструктивний. У таблиці 2 схарактеризовано типову стратегію поведінки представників кожного з чотирьох типів особистісної компетентності майбутніх педагогів.

Таблиия 2

Характеристика типів особистісної компетентності майбутніх педагогів

\begin{tabular}{|c|c|}
\hline Тип & Характеристика \\
\hline $\begin{array}{c}\text { Продуктивно- } \\
\text { креативний }\end{array}$ & $\begin{array}{l}\text { Притаманне пошуково-перетворювальне ставлення до довкілля та } \\
\text { самої себе, цілісне бачення світу. Сприйнятлива, чутлива до } \\
\text { проблем; відкрита новому, змінює стереотипи з метою створення } \\
\text { нового. Мотивована на духовний розвиток, досягнення успіху, } \\
\text { творчу самореалізацію; збалансовані соціальні та індивідуальні } \\
\text { мотиви. Діє гнучко, продукує оригінальні ідеї, приймає самостійні } \\
\text { рішення, визначає власні цілі, домагається високих результатів у } \\
\text { навчальній та професійній діяльності, досягає високих стандартів } \\
\text { якості. Вирізняється гостротою мисленя, творчою уявою, } \\
\text { дотепністю, інтересом до парадоксів, здатністю аргументувати свою } \\
\text { позицію, сміливістю і незалежністю суджень і дій, почуттям гумору, } \\
\text { ризикованістю, стійкістю до пеешкод і конфліктів, високим } \\
\text { коефіцієнтом корисної дії. Гуманно ставитья до людей, вміє } \\
\text { товаришувати, підтримує і захищає інших. Самооцінка адекватна, } \\
\text { домагання, самовіддача та статус високі, поведінка упевнена і } \\
\text { врівноважена. Розвинене почутя власної гідності, прагнення } \\
\text { самовдосконалюватися. Реалізовані повноцінно усі потенціали, } \\
\text { задоволені життям. }\end{array}$ \\
\hline $\begin{array}{c}\text { Продуктивно- } \\
\text { реконструктивний }\end{array}$ & $\begin{array}{l}\text { Розвинена пізнавальна активність, прагнення самостійно внести } \\
\text { певні зміни у прототип - варіювати засоби, щось замінити, } \\
\text { доповнити або видалити, виконати відоме в інший спосіб, } \\
\text { перетворити, оновити його. Вдається до компіляції, поєднує } \\
\text { самодіяльність із використанням чужих результатів. Діє самостійно } \\
\text { у знайомих ситуаціях, зіткнення з труднощами провокує звернення } \\
\text { по допомогу, яку доцільно використовує. Характер поведінки } \\
\text { нестійкий: від впевненої - до невпевненої; емоційні переживання } \\
\text { плинні, настрій неврівноважений. Прагне домогтися успіху будь- } \\
\text { якою ціною, індивідуальні мотиви переважають над соціальними. }\end{array}$ \\
\hline
\end{tabular}




\begin{tabular}{|c|c|}
\hline & $\begin{array}{l}\text { Продуктивність діяльності середня: не вдається за короткий час } \\
\text { домогтися високих результатів. Самовіддача на початку діяльності } \\
\text { досить висока, у кінці знижується - частішають відволікання, } \\
\text { зменшується зосередженість, спадає темп роботи. У навчальній та } \\
\text { професійній діяльності прагне внести у зразок деякі зміни, оновити } \\
\text { прототип, виконати відоме в інший спосіб, щось додати, видалити, } \\
\text { скомпілювати. Виявляє певну міру наполегливості, відповідальності, } \\
\text { сприйнятливості. Віддаючи комусь-чомусь перевагу, певний час } \\
\text { зважує варіанти рішення, піддає сумніву їх доцільність. У } \\
\text { спілкуванні дотримується основних моральних норм, має певне коло } \\
\text { друзів, намагається командувати, більш-менш ефективно працює } \\
\text { разом з іншими за умови задоволення своєю роллю. Самооцінка та } \\
\text { домагання визнання завищені, картина світу наближена до реальної. } \\
\text { Потенціали реалізовані нерівномірно, життям в цілому задоволені. }\end{array}$ \\
\hline $\begin{array}{c}\text { Продуктивно- } \\
\text { відтворювальний }\end{array}$ & $\begin{array}{l}\text { Пізнавальна активність невисока, віддає перевагу нескладним і } \\
\text { знайомим видам роботи, новизна в них практично відсутня } \\
\text { Повторює прототип, копіює зразок без змін, старанно відтворює вже } \\
\text { відоме, прагне чітко виконати вимоги викладачів, зробити, «як } \\
\text { вимагають», «як треба». Самооцінка недекватна, занижена, } \\
\text { домагання низькі, не довіряє своїм можливостям і здібностям. } \\
\text { Картина світу усічена, обмежена, фрагментарна. Соціальна } \\
\text { мотивація переважає над індивідуальною. Намагається не стільки } \\
\text { досягти успіху, скільки уникнути неуспіху. Зіткнення з труднощами } \\
\text { лякає, вона губиться, поводиться невпевнено у незнайомій ситуації. } \\
\text { Легко звертається по допомогу, залежить від авторитетних інших, } \\
\text { їхнього контролю, підтримки і оцінки. Орієнтується на моральні } \\
\text { норми і цінності, чутлива до проблем оточуючих, охоче їм } \\
\text { допомагає. Запопадлива у стосунках з успішними та упевненими в } \\
\text { собі студентами, легко піддається впливу, погоджується з їньою } \\
\text { думкою, відмовляєтьяя від власної думки. Продуктивність } \\
\text { діяльності невисока, ефективнсть дій та поведінки досить низька, } \\
\text { витрачає чимало часу на виконання мінімального завдання. } \\
\text { Потенціали реалізовані помірно, життям задоволені частково. }\end{array}$ \\
\hline Деструктивний & $\begin{array}{l}\text { Характеризується контрпродуктивною активністю, низьким рівнем } \\
\text { соціальної інтеграції, небажанням виконувати основні соціальні ролі } \\
\text { - студента, товариша, вихователя дошкільного закладу. Практичні і } \\
\text { вербальні прояви носять руйнівний характер, містять елементи } \\
\text { насилля - фізичного, психологічного (переважно у сфері } \\
\text { комунікації). Не довіряє довкіллю, бачить у ньому загрозу для себе, } \\
\text { прагне захищатися, ототожнює себе } 3 \text { агресивним оточенням. Не } \\
\text { дотримується норм моралі, протиставляє себе їм, поводиться } \\
\text { надміру ризиковано, не співвідносить причини і наслідки, прояви } \\
\text { творчості негативно забарвлені. Почувається відчуженою, часто - } \\
\text { безпорадною, нереалізованою. Емоційно імпульсивна, песимістично } \\
\text { налаштована. Енергію використовує переважно не за призначенням, } \\
\text { продуктивність навчальної і професійної діяльності надзвичайно } \\
\text { низька. Прагне завищити свій статус, виділитися серед інших } \\
\text { демонстративною поведінкою, порушенням правил співжиття, } \\
\text { татуюванням, пірсингом, екстравагантною зачіскою або одягом, } \\
\text { споживанням алкоголю, наркотиків. Демонструє свою зневагу } \\
\text { слабшим, критикуєї, погрожує, ображає. Більшість часу перебуває } \\
\text { наодинці. Уявлення про світ та саму себе деформовані. Потенціали } \\
\text { реалізовані мінімально й нерівномірно, життям незадоволені. }\end{array}$ \\
\hline
\end{tabular}

Як засвідчує спостереження, здатними до продуктивно-креативного типу особистісної компетентності виявили у різних групах 10-15\% студентської молоді; до продуктивно-реконструктивного - близько 30-35\%; до продуктивно-відтворювального 
- 40-50\% ; деструктивного - 5-10\% майбутніх педагогів. Отже, на часі оптимізація освітнього процесу, спрямованого на формування у майбутніх педагогів дошкільної освіти особистісної компетентності продуктивно-креативного та продуктивно реконструктивного типів.

До основних психолого-педагогічних умов розвитку особистісної компетентності студентської молоді віднесено:

- розвиток рефлексивних рис особистості, адекватного Я-образу;

- формування цілісної реалістичної картини світу, наукового світогляду та смислу життя - особистого та професійного;

- вправляння в умінні довіряти особистісному досвіду, поводитися упевнено, мобілізовуватися на долання перешкод та досягнення успіху;

- виховання системи духовних цінностей;

- забезпечення балансу соціальних та індивідуальних потреб, професійних та особистих інтересів;

- прищеплення корисних звичок: час від часу заглядати всередину себе, звертати увагу на свої почуття;

- утверджуватися у своїх намірах; підтримувати себе у складних ситуаціях;

- тримати оптимальний темп життя; не брати на себе забагато;

- не боятися провалів і помилок;

- визнавати чесноти інших, довіряти певному колу людей, прощати.

Упровадження вказаних умов у педагогічний процес закладів вищої освіти сприятиме покращанню показників особистісної компетентності.

Висновки і перспективи подальших розвідок. Особистісна компетентність $\epsilon$ інтегральною характеристикою майбутнього фахівця, яка засвідчується його здатністю свідомо мотивувати, організовувати, регулювати, контролювати та адекватно оцінювати результативність своєї життєдіяльності й вкладених у неї особистісних зусиль, творчо й соціально прийнятно самовиражатися, ефективно розв'язувати проблеми, реалізовувати свої потенційні можливості, орієнтуватися на духовні цінності, набувати індивідуального досвіду, домагатися життєвого успіху. Схарактеризовано типи особистісної компетентності майбутніх фахівців дошкільної освіти: продуктивно-креативний, продуктивно-реконструктивний, продуктивновідтворювальний та деструктивний. Психолого-педагогічними умовами формування особистісної компетентності визначено: розвиток рефлексивних рис особистості; формування цілісної реалістичної картини світу, наукового світогляду та смислу життя; вправляння в умінні довіряти особистісному досвіду; виховання системи духовних цінностей; забезпечення балансу соціальних та індивідуальних потреб, професійних та особистих інтересів; прищеплення корисних звичок.

До перспективних напрямів, що вимагають подальшого поглибленого вивчення, віднесено: розробку моделі оптимізації освітнього процесу закладу вищої освіти 3 метою формування особистісної компетентності студентської молоді; створення психолого-педагогічного забезпечення вказаного напряму освітньої роботи; забезпечення наступності у формуванні особистісної компетентності майбутніх фахівців дошкільної та початкової шкільної ланок освіти.

\section{СПИСОК ВИКОРИСТАНИХ ДЖЕРЕЛ}

Сериков, В. (1998). Личностно ориентированное образование: поиск новой парадигмыл. Москва. 180 с.

Кремень, В. (2002). Поступ до нової філософії освіти в Україні. Розвиток педагогічної і психологічної наук в Україні 1992-2002.Харків: «ОВС», Ч.1. с. 9-23

Синенко, Т. (2009). Личностная компетентность студентов педагогического вуза: сущностные характеристики. Известия Волгоградского гос. ун-та. Серия Педагогика. c.19-22. 
Введенский, В. (2003). Моделирование профессиональной компетентности педагога. Педагогика, 10, с. 51-55.

Маркова, А. (1996). Психология профессионализма. Москва: Международный гуманитарный фонд Знание. 312 с

Сергеев, Н. (2013). Педагогическая деятельность и педагогическое образование в инновационном обществе. Москва: Логос. 363 с.

Равен, Дж. (2002). Компетентность в современном обществе: выявление, развитие и реализация. Москва: «Когито-Центр». 396 с.

Корнеев, П. (1985). Жизненный опыт личности. Москва: Политиздат. 128 с.

Дружилов, С. (2002). Индивидуальный ресурс профессионального развития. Актуальные проблемы современной науки, 4 (7), с. 269-272.

Леонтьев, Д. (2011). Введение: личностный потенциал как объект изученияю. Личностный потенциал: структура и диагностика. Москва: Смысл. с. 2-7.

\section{REFERENCES}

Serikov, V. (1998). Lichnostno orientirovannoye obrazovaniye: poisk novoy paradihmy. [Personally Oriented Education: the Search for the New Paradigm]. Moskva. 180 s. (in Russian)

Kremen, V. (2002). Postup do novoi filosofii osvity v Ukraini [Progress Towards a New Philosophy of Education in Ukraine]. Rozvytok pedahohichnoi i psykholohichnoi nauk $v$ Ukraini 1992-2002. Kharkiv: "OVS”. Ch. I. s. 9-23. (in Ukrainian)

Sinenko, T. (2009). Lichnostnaya kompetentnost studentov pedagogicheskogo vuza: sushchnostnyye kharakterystyky [Personal Competence of Students of the Pedagogical College: Essential Characteristics]. Izvestiya Volgogradskogo hos. un-ta. Seriya Pedagogika.- s.19-22. (in Russian)

Vvedenskiy, V. (2003). Modelirovaniye professionalnoj kompetentnosti pedagoga [Modeling the Professional Competence of the Teacher]. Pedagogika, 10, s. 51-55. (in Russian)

Markova, K. (1996). Psikhologiya professionalizma [Psychology of Professionalism]. Moskva: Mezhdunarodnyj humanitarnyj fond Znaniye. 312 s. (in Russian)

Sergeyev, N. (2013). Pedagogicheskaya deyatelnost i pedagogicheskoye obrazovaniye v innovatsionnom obshchestve [Pedagogical Activity and Pedagogical Education in an Innovative Society]. Moskva: Logos. 363 s. (in Russian)

Raven, Dzh, (2002). Kompetentnost v sovremennom obshchestve: vyyavleniye, razvitiye $i$ realizatsyya [Competence in Modern Society: Identification, Development and Realization]. Moskva: "Kogito-Tsentr". 396 s. (in Russian)

Korneyev, P. (1985). Zhiznennyj opyt lychnosti [Life Experience of an Individual]. Moskva: Politizdat. 128 s. (in Russian)

Druzhilov, S. (2002). Individualnyi resurs professionalnogo razvitiya [Individual Resource for Professional Development]. Aktualnyye problemy sovremennoy nauky, 4 (7), s. 269-272. (in Russian)

Leontev, D. (2011). Vvedenie: lichnostnyi potentsyal kak objekt izucheniya [Introduction: Personal Potential as an Object of Study] Lychnostnyi potentsial: struktura $i$ diagnostika]. Moskva: Smsyl. s. 2-7. (in Russian) 


\title{
PERSONAL COMPETENCE OF THE FUTURE TEACHER: CONTENT, STRUCTURE, CONDITIONS OF FORMATION
}

\author{
Kononko Olena \\ Doctor of Sciences (in Psychology), Professor, \\ Head at the Department of Preschool Education, \\ Nizhyn Mykola Hohol State University, \\ Nizhyn, Ukraine \\ ORCID: 0000-0003-2815-6261 \\ e-mail: kononko11@ukr.net
}

\begin{abstract}
The material covers conceptual and technological approaches to the problem of formation of personal competence of future preschool teachers. Their relevance is due to a lack of theoretical and experimental studies of a specific direction, transformation of moral and spiritual values of modern youth, demand for higher education institutions information on ways of effective formation in the future pedagogical staff of personal competence as a complex and extremely important phenomenon. "Personal competence" means an integral characteristic of a future specialist, which is evidenced by his ability to consciously motivate, organize, regulate, control and adequately evaluate the performance of his life and his personal efforts, creatively and socially expressive problems potential opportunities, focus on spiritual values, gain individual experience, achieve life success.. Criteria for evaluating the type of forms vanosti personal competence served: a measure implementing future teachers of preschool education of their intellectual, emotional values, social, moral, volitional and reflective capacities; display of creative activity, high productivity of educational and pedagogical activity, life satisfaction. There are four types of personal competence: productive - creative (potentials are fully realized, productivity and satisfaction is high, focused on creating a new one), productive - reconstructive (potentials are uneven, productivity is above average, modifies the known, in whole reproductive (potentials realized moderately, productivity average, copies known, life satisfied partially) and destructive (potentials realized minimum $\mathrm{O}$ activity counterproductive, unhappy life). The conditions for the effective formation of social competence in a higher education institution are: the development of reflexive personality traits adequate to self-image; forming a holistic realistic picture of the world, scientific worldview and meaning of life; exercise in the ability to trust personal experience; education of the system of spiritual values; ensuring a balance of social and individual needs, professional and personal interests; instilling useful habits.
\end{abstract}

Keywords: potential and actual, personality potentials, life experience, vitality of the individual, creativity, personal competence, balance of individual and social interests.

Стаття надійшла до редакиії 30.09.2019 p. 